\title{
UMA OCORRÊNCIA SINGULAR DE SELENITA EM GEODOS NOS BASALTOS DA REGIÃO DE PLANALTO, RS
}

\author{
P.L.Juchem ${ }^{1}$ \\ D.P.Svisero ${ }^{2}$ \\ T.M.M.Brum ${ }^{3}$ \\ C.P.Prado 4
}

As rochas vulcânicas da Formação Serra Geral são a principal fonte de gemas no Estado do Rio Grande do Sul (JUCHEM et al., 1990; Anais, 36² Cong.Bras.Geol., 3:1436-1449). Nessas rochas ocorrem extensas jazidas de ágata e ametista, as principais gemas produzidas no Estado, em depósitos do tipo "Geodo em Basalto". Essa Formação é constituída por vários derrames superpostos e descontínuos, com espessuras de 1 a 40 metros, cuja composição é predominantemente de basaltos tolefticos e seus equivalentes intrusivos, diabásios e gabros, com variações locais para basaltos alcalinos $\theta$ andesito basaltos. Localmente, são observadas lavas dacticas e rioliticas recobrindo os últimos derrames. É comum nessas rochas, a ocorrência de geodos, mineralizados ou não, com dimensões e formas bastante variadas. As formas mais freqüentes são as arredondadas e as ovóides, bem como geodos com contorno cilíndrico alongado, aparecendo também formas irregulares. As dimensões oscilam desde poucos centímetros até 2 a 3 metros de comprimento.

A extração dos geodos mineralizados é feita em garimpos que podem se desenvolver na rocha alterada ou na rocha sã. O primeiro caso é típico na região do município de Salto do Jacul, onde estão localizadas as principais jazidas de ágata do Estado. Nessa localidade, os

\footnotetext{
1Pós-graduação, Departamento de Mineralogia e Petrologia, Instituto de Geociências, USP e Instituto de Geociências, UFRGS.

${ }^{2}$ Departamento de Mineralogia e Petrologia, Instituto de Geociências, USP.

Instituto de Geociências, UFRGS.

4 Iniciação Científica, Instituto de Geociências, UFRGS.
} 
geodos são extraídos da rocha alterada, em garimpos a céu aberto; onde a coerência da rocha permite, são abertas pequenas galerias na camada mineralizada. Já na região do Alto Uruguai (norte do Estado), os garimpeiros trabalham a rocha inalterada. Nessa região, em uma área de aproximadamente $200 \mathrm{~km}^{2}$, compreendendo parte dos municípios de Planalto, Iraf́, Frederico Westphalen e Rodeio Bonito, estão localizadas as mais importantes jazidas de ametista do Rio Grande do Sul. Com o uso de explosivos e ferramentas manuais, os garimpeiros abrem na rocha sã várias trincheiras e galerias horizontais, que podem atingir até 100 metros de extensão. Os geodos que vão aflorando são então extraídos manualmente, com o auxllio de martelo e talhadeira.

Nos geodos são encontradas mineralizações de quartzo (variedades ametista, cristal de rocha, leitoso e citrino), calcedônia (ágata, ônix e jaspe), opala (comum e opala de fogo), calcita, apofilita e zeólitas (natrolita, escolecita, heulandita, estilbita, laumontita, ptilolita). Mais recentemente, foram descobertos geodos mineralizados com selenita, uma variedade hialina de gipsita, em cristais sempre bem desenvolvidos.

A selenita ocorre na forma de cristais euédricos, monoclínicos, incolores e transparentes, de hábito prismático a tabular e com dimensões de até 1 metro de comprimento. São comuns os agregados paralelos e as formas cristalinas bem definidas. Foram identificados os prismas $\{h k O\},\{O k 1\},\{h k 1\},\{h k 1\}$, os pinacóides $\{001\},\{010\}$, e o pinacóide obliquo $\{101\}$. O pinacóide lateral $\{010\}$, cujas faces coincidem com a direção de clivagem principal, apresenta-se sempre límpido e vitreo, enquanto que as faces das demais formas podem se mostrar embaciadas ou estriadas. Ocorrem ainda as clivagens (100) e (011), menos desenvolvidas, mas de fácil identificação. A dureza baixa, de valor 2 na escala de Mohs, foi confirmada em fragmentos de clivagem. Examinados ao microscópio polarizador, os cristais mostram-se límpidos e isentos de defeitos, exibindo caráter biaxial positivo, sem anomalias ópticas. Os índices de refração medidos com refratômetro gemológico, utilizando-se luz monocromática amarela (589 nm), acusaram os valores $\alpha=1,517 ; \beta=1,521$ e $\gamma=$ 1,527 , resultando uma birrefringência de 0,010 . Junto com a selenita, aparecem associados ou como inclusões, cristais de zeólitas fibrosas, calcita com hábito romboédrico e escalenoédrico (dente de cão), pequenos cristais prismáticos euédricos de quartzo leitoso, bem como pacotes de agregados microcristalinos silicosos em forma de cunha aguda, que lembram moldes de cristais, resultantes provavelmente da substituição de anidrita por silica. São freqüentes ainda, fragmentos irregulares de geodos com ágata e ametista, parcialmente incluídos nos cristais de selenita.

É importante salientar, que essa ocorrência notável de selenita só foi descoberta há aproximadamente dois anos e é restrita a um único garimpo localizado no município de Planalto, em uma região onde existem mais de 200 garimpos de ametista. Existem registros de selenita em duas 
outras localidades no Rio Grande do Sul; no município de Arvorezinha, em geodos centimétricos e no município de Três Passos, em testemunhos de sondagem. Contudo, até o presente momento, essas duas ocorrências são desprovidas de interesse econômico.

A origem dessa selenita é ainda desconhecida e atualmente está sendo objeto de estudos mais detalhados. A presença de gipsita, registrada somente em poucos locais do Estado e sempre em ocorrências de pequena extensão geográfica, sugere que a origem desse mineral possa estar relacionada com a presença de pequenos lagos existentes no deserto Botucatu. As rochas sedimentares da Formação Botucatu, que estão sob os basaltos da Formação Serra Geral, teriam antigos depósitos de gipsita e/ou anidrita sedimentados em lagos desérticos, que poderiam servir de fonte para a cristalização de gipsita nos geodos das rochas vulcânicas sobrejacentes.

As dimensões, a transparência e o idiomorfismo dos cristais de selenita, sugerem que a ocorrência de Planalto é um caso único e excepcional, sem equivalente na literatura mineralógica. Em função dessas características, o material garimpado é comercializado como amostras de coleção, sendo exportado regularmente para os países desenvolvidos. Algumas lojas em Soledade e Planalto (RS), e em São Paulo e Embu (SP), possuem peças de excepcional beleza para comercialização, cujos preços podem ocilar desde 100 até 10.000 dólares o exemplar. 